\title{
Process Reengineering in African Public Sector: Lessons From the Private Sector
}

\author{
Fatile, Jacob Olufemi, PhD \\ Department of Public Governance, \\ School of Management, IT and Governance, \\ University of Kwazulu-Natal, \\ Durban, South Africa. \\ Mutereko Sybert, $\mathrm{PhD}$ \\ Department of Public Governance, \\ School of Management, IT and Governance, \\ University of Kwazulu-Natal, \\ Durban, South Africa.
}

\author{
Emma Etim \\ Department of Public Administration, \\ Faculty of Management Sciences, \\ Lagos State University, \\ Lagos, Nigeria
}

Received: Aug. 10, 2020 Accepted: Aug. 31, 2020 Online published: Sep. 13, 2020

doi:10.5296/jpag.v10i3.17688

URL: https://doi.org/10.5296/jpag.v10i317688

\begin{abstract}
Process reengineering (PR) is a newly introduced approach to process management; it pays close attention to all the processes that are related to the achievement of organizational objectives. Although originally developed for and applied in the private sector, PR is expected to constitute a handy tool for the transformation of work processes in public sector
\end{abstract}


organizations (PSOs), especially in this era of information and communications technology. This paper X-rays PR in African public sector organizations (APSOs) with an emphasis on lessons to be learnt from the private sector. This paper adopts a descriptive approach, to validate and modify extant theoretical models that are relevant in explaining PR in APSOs. The paper observes that APSOs, unlike the private sector organizations (PrSOs), PSOs have failed in the adoption of PR as well as carrying out logically related tasks in such a way that well-defined results are achieved. It reveals further that poor PR in APSOs has been a clog in the wheel of achieving high performance, efficient service delivery, public satisfaction, efficient management of resources, and sustainable development in Africa. This paper concludes that APSOs can fully adopt PR if they cut down on excessive bureaucracy and learn more from the private sector in terms of readiness and adaptability to environmental changes and transformation as advocated by the contingency theory (CT). The paper recommends, amongst others, that there should be the availability of information technology (IT) infrastructure and the willingness on the part of government representatives to deploy new technologies through adequate support for information technology companies and the prioritization of IT application's needs for high system automation. Managers of APSOs should be given the power to effect changes when the need arises, without any form of influence. Also, there should be concerns about the future of PSOs, and citizens who are clients thereof should be held in high esteem and not to be treated as 'people in need of favour'. Finally, APSOs should embrace radical changes associated with PR especially by ensuring that promotions are based on merit and not on seniority alone.

Keywords: bureaucracy, process reengineering, information technology, performance, service delivery

\section{Introduction}

Public administration has been in existence in Africa for many decades now and still operates with its hierarchical fashion and central management principle which offers highly bureaucratic and delayed services that stands against enhancement, duty focus, and excellence (Bokhari \& Qureshi, 2016). Although many African governments have adopted information technology (IT) infrastructures to deliver some services to the citizens, at the moment, these operations are merely the reflection of the actual bureaucratic operations as the continent is yet to undergo a total and radical process reengineering (PR) to achieve marked improvements in terms of performance. Excessive bureaucracy as practised in African public sector organizations (APSOs) have been a clog in the wheel of rapid and sustainable development, service delivery, and public satisfaction with government-owned enterprises. PR explains possible ways, in which organizations can adequately apply IT to routine activities, restructure and modernize organizational processes as well as develop the employees to act in consonance with the new organizational outlook for maximum performance, sound service delivery, public satisfaction and efficient management of resources. The adoption of PR in APSOs will provide an excellent opportunity for high performance, better customer service and a better way to manage resources in the interest of the public (clients). Oberoi (2013) observes that PR comes after a broader concept of new public management (NPM) and is expected to amalgamate organizational processes, 
introduce enhanced computerization and remove unnecessary actions that cause delays in APSOs.

Although public sector organizations (PSOs) have unique attributes that differentiate them from the private sector organizations (PrSOs), it can adopt PR for better organizational processes and performance if it learns from the private sector's critical successes and failure factors through the adoption of an improved strategy to accrue relevant PR resources and capabilities, the mobilization and application of all skill sets, systems and technologies that are essential in improving PR impacts as well as the development of strategies to overcome every barrier to PR implementation and sustenance. This paper examines the impact of PR on APSOs' service delivery and public satisfaction, and how resources can be effectively managed to produce results that will aid sustainable development in Africa through the lens of the contingency theory, which explains the influence of the environment on organizational leadership, the need for IT application as well as the need to give managers the power to effect rapid changes when the need arises without any form of influence, as seen in many PrSOs. Here, attention will be paid to Venkatraman's (1994) model for reengineering APSOs, primary barriers to APSO's PR, critical success and failure factors of PR, why APSOs need PR, the role of IT in PR and functional methodology for the application of PR in APSOs.

\section{Statement of the Problem}

Today, both public and private organizations experience fundamental changes as a result of the swift advancement in information technology (IT), environmental changes, competition and the need for prompt service delivery. This requires managers to pay close attention to all the procedures that are related to the transformation of work processes as well as the achievement of organizational objectives. Although PR was initially developed and applied in the private sector, it is today considered as a handy tool for the transformation of work processes in PSOs, especially in this era of IT and as a result of the present day changes in the work environment. PSOs in Africa have been faced with numerous problems mostly attributed to excessive bureaucracy, work procedures, and systems that are hard to deal with, not limited but, corruption and inability to focus on customer (public) service as well as manager's inability to effect rapid changes due to excessive bureaucracy. APSOs unlike the PrSOs, have often failed in carrying out a logically related task in such a way that well-defined results are achieved. This problem is a 'clog in the wheel' of achieving high performance, sound service delivery, public satisfaction, efficient management of resources and hinders sustainable development in the continent.

It is instructive to note that several studies have been conducted on public sector and PR, however, less attention has been paid to APSOs which have been noted for its continuous poor performance in terms of public satisfaction and organizational development (Vrček, Brumec, \& Ibrahimpašić, 2009; Simasiku, \& Ngoma, 2018). Some previous studies focused more on developed economies like Australia, England, the United States of America, and New Zealand, which are already ahead with the use of newer techniques of public administration (Martins \& Montagna, 2006). Extant literature has also revealed that private sectors in Africa are far ahead of APSOs in the application and management of IT 
infrastructure for modernized and efficient service delivery (Lucas, 2016). Meanwhile, few studies on PR in APSOs focused mainly on descriptive surveys without deep theoretical model explanations and consideration for regional ecological factors. A critical review of the extant literature on PR further revealed that most of the studies concentrated on the applicability of PR as seen in Scholl (2003) and MacIntosh (2003); PR description (Sia \& Neo, 2008; Debela \& Hagos, 2011); the depth and breadth of process reengineering in the public sector as well as how public sector PR is unique (Anderson, 2006). It is this identified gap in the literature that forms the basis of the discourse in this paper. The paper, therefore, attempts to re-validate some theoretical models that have proven valid in explaining the importance of applying the principles of process reengineering in APSOs with clear empirical evidence from the extant literature review. More specifically, attempt is made in the article to explain:

a. Venktraman's model for reengineering APSO's work process,

b. the primary barriers to APSO's PR,

c. modify Abdolvand et al (2008) model of critical success and failure factors of PR,

d. why APSOs need PR,

e. the role of IT in PR, and

f. methodology for the application of PR in APSOs

In line with the above stated objectives, the article seeks to provide answers to the following questions in an attempt to underscore the relevance of PR in APSOs.

i. What are the primary barriers to APSO's PR?

ii. What are the critical success and failure factors of PR

iii. Do APSOs need PR?

iv. What are the roles of IT in PR?

v. Is there any methodology that can aid the application of PR in APSOs?

\section{Methodology}

This paper adopts a descriptive approach to validate some theoretical models that are relevant in elucidating PR in APSOs. It relies heavily on models derived from a critical review of extant literature (secondary data). Each of the models discussed pertinent issues under selected themes and sub-themes within the paper using structural and procedural diagrams that are designed in an understandable and self-explanatory format. Some of the models have also been modified by the authors to further fit in the context of this discourse. This methodological approach typifies the qualitative mode of inquiry which the paper typically exemplifies. 


\section{Conceptual Review}

\section{Process Reengineering $(P R)$}

Different concepts have been used to describe PR. These include new industrial engineering, working smarter, and core process redesign. Although the concept of PR has received the attention of scholars, little has been published about the subject matter in APSOs. There is no doubt that there are still several questions that are yet to be answered particularly concerning the processes and the method that can be used to effectively implement PR (Bhaskar, 2018). According to Mekonnen (2019:109) "PR is the fundamental rethinking and radical redesigning of an entire organizational system - the process, jobs, organizational structures, management systems, values, and beliefs to achieve dramatic improvements in critical measures of performance, such as cost, quality services, and speed".

PR can be described as a tool for process change and management as well as the transformation of the work process. It connotes all procedures needed for the optimizing organizational processes and structures to achieve the best possible result (Bhaskar, 2018). The role of PR in engendering organizational improvement in terms of productivity and performance as seen in previous studies by Hussien et al $(2013,2014)$ and Essam and Mansar (2012) was not incorporated in Bhaskar's study. Here, PR is seen as a tool to promote organizational efficiency, most especially in terms of time and cost (Hussein et al., 2014; Essam \& Mansar, 2012). There is no doubt that in the last few decades, private sector organizations have tried to improve in the way they manage their work processes as a result of increasing demands by customers for better products and services (Hussein et al., 2013; Dutta, 2007).

PR can be used in a whole organization (Goksoy et al., 2012), a part of it, or even a single unit within the organization. Habib \& Shah (2013) posits that organizational performance can be enhanced through PR which remains one of the newly introduced approaches to process management that can bring about a radical change. PR explains possible ways in which organizations can adequately apply IT to routine activities, restructure and modernize organizational processes as well as develop the employees to act in consonance with the new organizational outlook for maximum performance, sound service delivery, public satisfaction and efficient management of resources. Bhaskar (2014) observes that information technology has an important role to play in PR most especially in improving the level of performance in public and private organizations. Again, attention needs to be paid to the tendency of misuse of technology in organizational processes, an aspect that has been ignored by Bhaskar. It is on this note that scholars like Morabito (2013) and Amanquah et al (2013) advocate that the introduction of computers in solving an existing organizational problem does not necessarily cause the process to be reengineered. The likelihood of misuse of technology can block reengineering and lead to the reinforcement of old ways of thinking and old behavior patterns.

\section{Public versus Private Sector Organizations}

PSOs are government-owned enterprises that are established to provide essential services to 
the citizens. PSO is not a profit-seeking venture. They are established to generate funds through taxes, fees, and loans. In the words of Callender (2001:1), "PSOs are entities that have been formed to manage the policy and operating requirements that enable a government to achieve its goals of public governance". PSOs are not-for-profit entities that are established by the government to manage its (government) policy and operating requirements for public satisfaction. PSOs in Africa have been known for their wastefulness, inefficiency, high level of corruption, bureaucratic bottleneck, and inability to achieve its core objectives which usually include good service delivery and public satisfaction (Nchuchuwe \& Etim, 2020). $\mathrm{PrSO}$, unlike PSO, is owned and run by private individuals for profit generation. The private organization is established in the form of corporations, partnership, agency, etc. These sector makes up a greater part of the economy and is very viable in a capitalist system of government where private property ownership is most preferred to collective or communal ownership. The private sector over the years has been more effective and efficient as compared to the public sector. The private sector continuously develops strategies to enhance performance and efficient resources management. This attribute stands as a plus to the private sector and remains lacking in PSOs, especially in Africa.

Owing to the adoption of privatization policy by many countries of the world today, the private sector is also gaining relevance as compared to the era when only the public sector was prevalent in the economy (Surbhi, 2018). For any country to develop and progress, both the private and public sectors must own up to, and deliver adequately on their respective economic responsibilities, and where necessary, both sectors collaborate in the interest of the national economy. The private sector is owned and controlled by individuals and, most often than not, are for profit-making, whereas, the public sector is controlled by the government. The public sector includes all business enterprises that are owned and managed by the government. Figure 1 below shows some basic features of the PSOs and PrSOs.
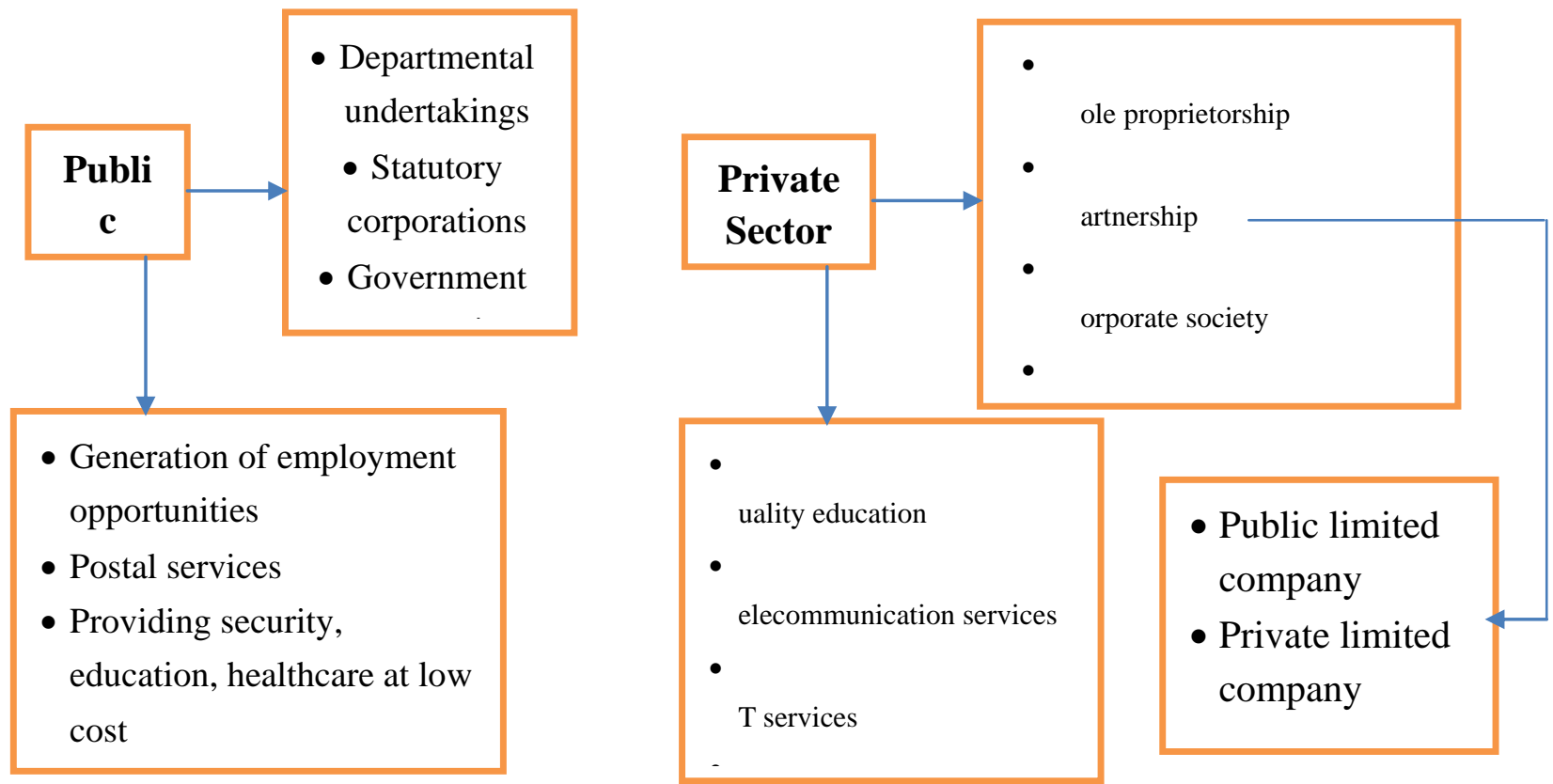

Figure. 1. Public versus Private Sector Organizations 
Source: Surbhi (2018).

From figure 1, it is clear that PSOs carryout departmental undertakings, statutory corporations and are government companies created to generate employment opportunities, delivering on postal services, providing security, education, healthcare, and railway services at a lower cost. On the other hand, the PrSOs are owned and operated by sole proprietors, with options of partnership where necessary. Some of the major services provided by the public sector are educational services, IT services, courier services, telecommunication services, and infrastructure development. Scholars have observed that the government is a bad manager with an incremental decision-making approach and excessive bureaucracy (Khan \& Khandakar, 2016). The distinction in the basic features of the public and PrSOs have made the application of PR easier in the later when compared to the former.

The environment at which the private sector operates remains highly competitive. Hence, there is need for a rationalized decision-making approach and the adoption of modern technologies that have been designed to promote clients' satisfaction, and organizational efficiency and effectiveness (Sujová \& Čierna, 2018). PrSOs have made headway in the application of PR due to the nature of the environment they operate which is made up of a countless number of competitors. However, APSOs have taken advantage of less competitive environments and monopoly in some cases to become redundant and less productive. Services rendered in APSOs include, but not limited to, security, electricity, less expensive education, and health. These services are cheap and sometimes free and are funded by taxes, penalties, loans, sales of natural resources, and etc, there is less competition and profits are not expected. The organizational structure of APSO is bureaucratic with poor change and managerial styles. Promotions are made on a seniority basis and not by merit as it is in the private sector. This makes the application of PR difficult in PSOs as less attention is paid to performance, especially in the ugly face of corruption.

\section{Theoretical Framework}

This paper is anchored on the contingency theory (CT). Historically CT originated as a result of researches conducted separately by scholars from Ohio State University and the University of Michigan in the 1950s. CT holds that specific situations can affect the leader's effectiveness. Hence, the manager needs to be able to adapt to these situations. Several factors determine the effectiveness of a leader or leadership style. These are; the leader's personality, the tasks at hand and the nature of people that constitute the group that is meant to be led (Islam \& Hu, 2012). CT was popularized by Fred Fiedler in the early 1960s. Fiedler debunks the idea of having a single best way of organising or leading an organization (Fiedler, 1964; Fiedler, 1986). Earlier, in 1958 Joan Woodward suggested that there is a need for an organisational structure to be put in place to allow for the deployment of different technologies. In the words of Scott (1981) "the best way to organise depends on the nature of the environment to which the organisation must relate". This lends credence to Woodward's argument on the need to make use of different technologies, because technology is an enabler of process re-engineering and it eases communication stress, introduce new features and promote positive change in the work environment. 
CT challenges the positions of the bureaucratic and scientific management theories, as the duo neglect the fact that various aspects of the environment (or all the contingency factors) influence organisational structure and the style of management. Although the scientific management school contributes to PR in the sense that it acknowledges the importance of educating and strengthening employee skills and knowledge which is a key factor of PR, the theory failed to address the need for the independence of managers (Uddina \& Hossain, 2015; Gull, 2017). This has been a ' clog in the wheel' of successful PR, since managers need to possess powers to exhibit their leadership potential without any form of influence. Using the lens of the CT, the bureaucratic theory also stands as a major hindrance to APSO's successful application of PR because it creates no room for radical changes to be applied by managers without following existing rules (Yazaki, 2016). From the bureaucratic theoretical perspective, organizational authority is expected to flow downward from the top (Samier, 2012; Kumar, 2016; Serpa \& Ferreira, 2019). This is accompanied by rigidity and unnecessary rules and regulations that are capable of delaying processes (Harney, 2016; Mori, 2017; Köybaşi, Uğurlu \& Bakir, 2017: Shaikh, Islam \& Jatoi, 2018).

To some extent, CT aligns with the system theory (ST) which holds that environments, space and time can influence the structure and functioning of the system. Here, alteration or change of one part may impact negatively or positively on the whole (Lai \& Lin, 2017). However, the point of divergence between the CT and ST is in the former's agitation for more powers to the manager to effects urgent and vital changes when they need arises. PR in APSO is important especially in the $21^{\text {st }}$ Century due to high-level competition and the ever-increasing demand for effectiveness and efficiency in public sector organisations. Today every organisation is expected to beat every obstacle along the way to optimise client satisfaction.

The CT also has some weaknesses as identified by critics of the theory. One of the identified weaknesses of the theory is in its inability to provide an adequate explanation for its submission that there is a correlation between contingency variables like technology and the structural features of an organization (Omoluabi, 2016). However, the three major aspects that make CT suitable for this paper are; first, its recognition of the importance of technology. Second, it recognizes the influence of the environment on leadership style (Omoluabi, 2016). Third, the call for more powers to the manager to make urgent decisions following changes in the environment. These three aspects have been major sources of PR's success in private sector organisations and there is need for APSO to also modernize its process in this manner, to achieve optimal performance and client satisfaction.

\section{The Role of Information Technology (IT) in PR and Organizational Performance}

IT and its infrastructure are known to be vital components for efficient and effective service delivery and automation in both public and private sectors. Through IT, features like teleworking, multimedia communication, virtual conference, online purchase, etc are made possible in a faster way. IT is known as an enabler in PR because it helps introduce new features and promotes positive change in the work environment (system redesign). According to Johnson (2011:7); "working together, PR and IT have the potential to create more flexible, team-oriented, coordinative, and communication-based work capability. It can fundamentally 
reshape the way business is done and enable the process redesign. Although PR and IT are natural partners, the potentials of these relationships have not been fully explored.

From the contingency theory's point of view, to transform APSOs, the relationship between IT and PR needs to be clearly defined and understood by top management. The major role of IT in APSOs is to enable new organizational forms as well as patterns of collaboration between the organization, its external partners, and within the internal system. This is done through the application of computers, software, and other business communication technologies. PR has triggered the use of IT to increase the speed of work and to do things differently in developed economies like the United States of America, Australia, New Zealand, to mention a few. In Africa, the private sector was the first to enjoy the dividends of IT in particular and PR in general. Sudhakar (2010) makes a good illustration of the role of IT in PR. In his words;

... With the advent of IT and communications technology, it is possible to roll out the product in days in current days. The marketing executive gathers the requirements and sends them to the design centre through the Internet. Then the design centre sends the designs through Internet or email to the manufacturing plant...

At this point, the importance of IT in PR cannot be over-emphasized. This is because when software tools are competently and effectively applied, PR stands more chances of achieving success. To maximize this potential, APSOs should develop on effective IT infrastructure, channel more investments to IT infrastructure, promote measures that are needed for IT infrastructure effectiveness, properly integrate IT, and effectively reengineer all IT legacies within the organization (Lilian, Uzochukwu, \& Francisca, 2015). Further, while top managers are expected to involve in this process through strategy formulation and the provision of commitment for the redesigning process, the IT managers should take charge of the designing and implementation processes.

There is no doubt that IT plays a vital role in PR. While PR is expected to enable the adoption and adequate application of IT, IT capacities, on the other hand, should support PR. This is evidence in the transformation of the unstructured work process into standardized transactions, easing of complex analytical methods, reducing human labour, attracting and managing vast volumes of business information, bridge distance gaps, allowing multiple tasks to be worked upon simultaneously, the connection of two or more parties without intermediaries, knowledge dissemination, and detailed tracking of status. All these processes lead to efficiency, effectiveness, and high performance in the organization. Effective and efficient performance by APSO will lead to sound service delivery and public satisfaction.

\section{Why APSOs Need PR}

Rezaie (2018) identified some organizational issues that APSOs face and why PR is necessary. These include; "ambiguity in purpose, complicated operation, low efficiency and low results. Organizational inefficiency and ineffectiveness are the main outcomes of such organizational problems which ultimately led to cclient dissatisfaction and may distance the people from 
government activities". Thus, there is a need for a total reengineering of the process. Rezaie also highlights some benefits which apply to PSOs in Africa, especially in the aspect of technology and process automation. African PSOs lack clarity of purpose as leaders and managers fail to understand every aspect of the business ranging from organizational mission to customer base.

Many PSOs in Africa operate as if they are rendering some sort of voluntary services to the people. This is not supposed to be the case. The people are to be treated as esteemed clients which they are. Hence, the introduction of PR in PSOs will address the need for more clarity of purpose and the leadership can re-familiarize itself with the organizational business and focus more on achieving the correct goals with the right information. Going by the doctrine of CT, when the purpose of PSOs is well understood by managers and employees, there is bound to be total streamlining of superfluous processes that usually slow down work processes. Hence, with more logical work processes, things move easier and more efficiently in the organization. This efficiency is seen in the management's focus as well as employees' dedication and willingness to invest more energy in the on-going meaningful work. A reengineering process helps in product improvement which results in the maximization of profit by the organization.

When APSOs fully adopt and apply all the vital principles of PR as seen in PrSOs, there will be excellent service delivery and public satisfaction. This will give room for public trust and confidence in public servants and APSOs' managers. Every citizen wishes for ease of transacting business and communicating with the government when the need arises through relevant organizations and authorities. This important aim can be achieved with IT. In Nigeria, the Joint Admission and Matriculation Board (JAMB) is making significant effort to fully apply IT in its operations. Though this move is not without challenges and criticisms, the result so far remains encouraging and to a greater extent applaudable with room for more improvements. IT is expected to make service delivery, efficiency, effectiveness, and public satisfaction a part of APSOs and this can be achieved with PR.

\section{Venkatraman's Model on the Levels of IT Application in Organizational Design}

The contingency theory lends credence to the position of the Venkatraman's model on the need to adopt IT in PSOs. Venkatraman discusses five (5) levels of IT application in organizational design as shown in figure 2 below. According to him, these 5 levels are further categorized into two (2) categories; evolutionary (efficiency-seeking level) and revolutionary (where capacity is being enhanced). The former includes localized exploitation, horizontal integration, and ends with business process redesigning, while the latter begins with business process redesigning to include business network redesign and scope redefinition. 


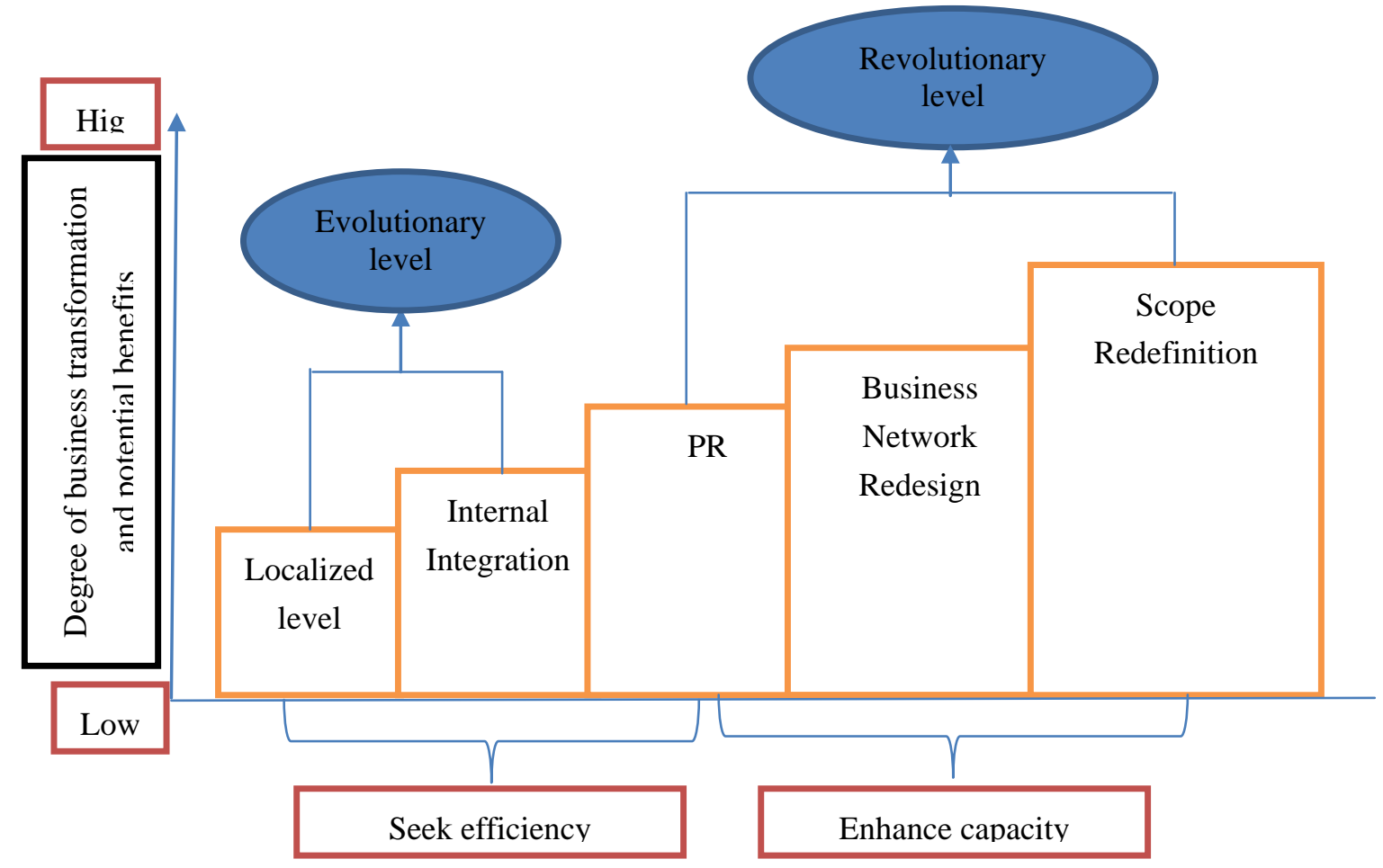

Figure 2. Venkatraman's model on the levels of it application in organizational design

Source: Venkatraman (1994:74).

Localized exploitation: at this level, ICT is applied to enhance employees' efficiency in the organization. This is the basic level of applying ICT potentials within the workplace. There are no mutual relations to this application. The major concern of this approach is efficiency and effectiveness (Prakken, 2000). In the words of Venkatraman (1994: 75), "the result of localized exploitation is minimal learning among managers within the organization of benefits and limitations from such initiatives. Typically, managers initiate and deploy these systems to respond to operational problems or challenges. For example, 24-hour toll-free customers care service support system to enhance service". One of the major advantages of this level is that it is relatively easy to spot out the potential IT capacity. However, there are indications that this level might likely fail, especially when assessed against best-in-class capability.

Internal integration: This level follows the localized exploitation level, with adequate attention paid to the re-arrangement of elementary activities to achieve a higher-level work process. At this level, the organization appreciates the centrality of ICT infrastructure. Just like the localized exploitation level, the internal integration level is an evolutionary level because very little changes are expected in the process. On the other hand, the other three levels that require enormous changes to the organizational routines. In the words of Debela (2009), "internal integration eliminates functional boundaries. For example, instead of having the seller, cashier, store man and accounting clerk to write invoices receive cash, record shipment and post the transactions respectively, a single system can be used to carry out the entire process, which defragments horizontally related tasks and is handled by one ICT 
oriented individual, instead of four different persons as the case would have been.

Business process design (reengineering): The difference between internal integration and PR is that while the former interlink different applications and systems to eliminate functional boundaries through the re-arrangement of the elementary activities to achieve high-level work process, the latter implies a complete renovation of the work process. This renovation is expected to take effect before the application of ICT to disable inefficient activities from being automated into the process. According to Venkatraman (1994:5), "research from the MIT management in the 1990s program strongly indicated that IT functionality should not be simply overlaid on existing work processes but should be used as a lever for designing the new organization and association's work processes". PR begins at the revolutionary level and radical changes are expected in the organizational practice. Reengineering the entire process not only leads to more efficiency but enhances competitiveness.

Business network redesign: After a successful overhauling and re-arrangement of the elementary activities, there is need to create room for strategic alliance and cooperation among business network participants. This includes, but not limited to linking the organization to both suppliers and clients. In the case of the public sector, the citizens are the customers. A well-designed business network will shorten distances, eliminate walls, and create more opportunities for partnership because services can be rendered to clients anywhere and anytime.

Redefining organizational scope: At this stage, emphasis is placed on how business scope is influenced by IT. Debela (2009: 33) wrote: "scope redefinition involves the rethinking of the mission of the organization, the business it is in, and the network it has with strategic partners and allies to bring a paradigm shift in the business activity". This is the level where IT is deployed to fast-track the repositioning of a firm's business scope.

Thus, Venkatraman's model highlights the need to progress from an evolutionary level to a revolutionary level of IT application in organizations. Many PrSOs like banks, insurance, and telecommunication have sufficiently moved from self-seeking IT level to an enhanced capacity level. Sadly, APSOs are still wallowing in the disadvantaged internal integration (self-seeking) level trying to link different systems and applications to make the work process more interdependent and functional (Venkatraman, 1994). This is not totally a bad idea, but it is far below expectations in the $21^{\text {st }}$ century where IT infrastructures, applications, and systems have been designed to suit different needs. It is not out of place for APSOs to move through these stages where business scope and relationship are influenced by IT (enhanced capacity). To achieve this, APSOs need to reduce its bureaucracy to give way to a contingency approach where the environment is expected to be a determinant factor of structure and processes within organizations. The present era demands faster, easy, and more reliable ways of dealing with the public, and this gap have been adequately filled by IT applications. It is expected of APSOs, therefore, to tap into this blessing for optimal performance in the interest of public satisfaction (Duke, Okudero, Etim \& John, 2020).

Primary barriers to PSO's PR (internal and external) 
Ghatari, Shamsi and Vedadi (2014) categorize the barriers to PSOs' process reengineering into five; political, technological, social, economic, and organizational as shown in figure 3 below.

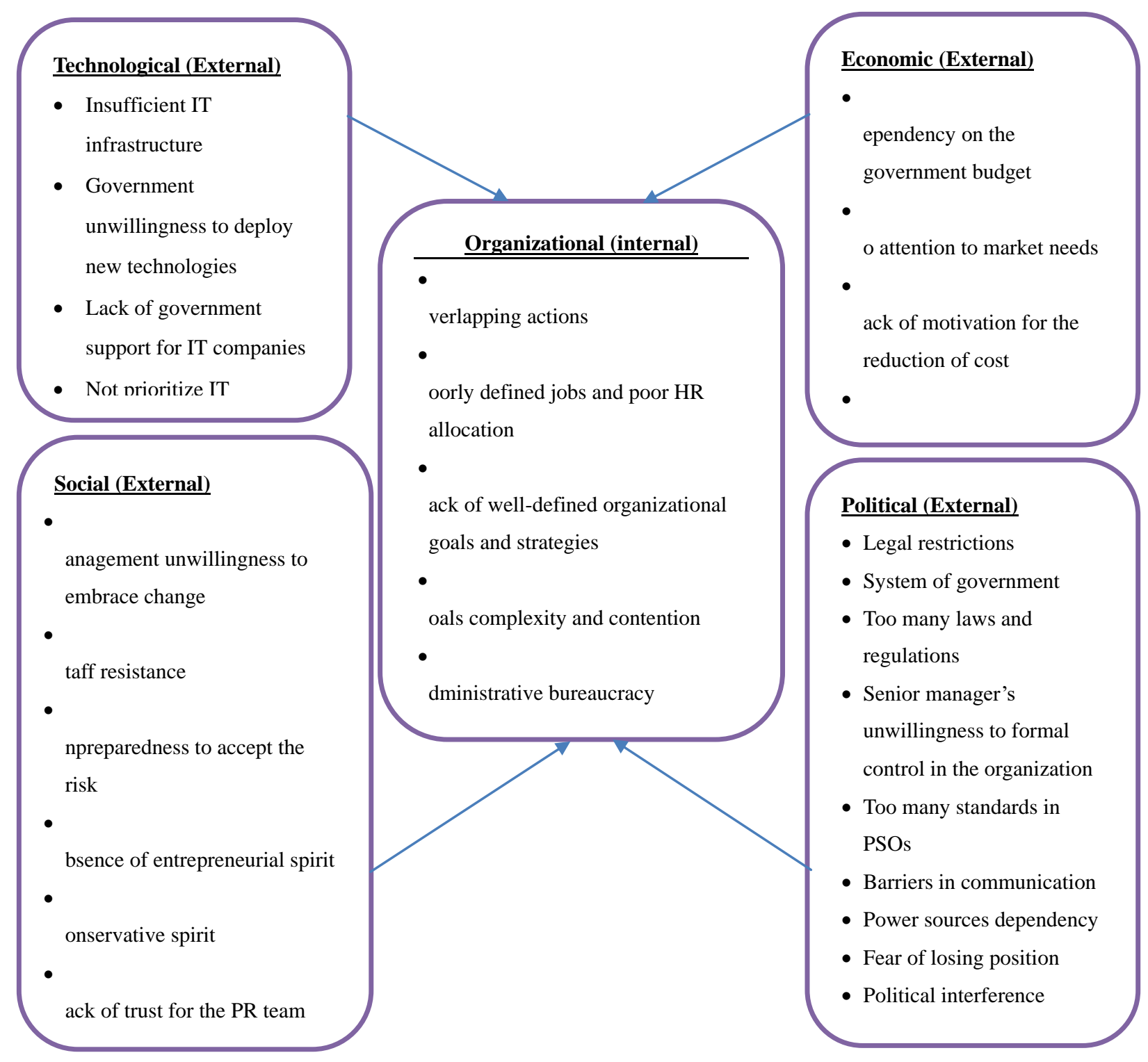

Figure 3. Ghatari et al's model

\section{Source: Ghatari, et al (2014) and authors' compilation}

As shown in the figure, the first four are external barriers that influence the internal barrier (organizational). Internal barriers are those factors within the organization, which stand against the achievement of laid down goals and objectives. APSOs have been faced with severe bureaucratic challenges that have rendered managers incapable of rapidly responding to vital changes without delay. For instance, recruitment into the Nigerian civil service is done through the office of the Head of Service, from where recruited persons are posted to various Ministries, Departments and Agencies (MDAs). Going by this process, it is difficult of managers (leaders) of respective MDAs to acquire the skill sets that are most appropriate 
to drive the affairs of the MDA at a given point in time. This situation meets a poorly defined jobs, poor staff training, inflexible decision making, goals complexity, contention, and insufficient (qualified) staff strength. To solve this problem, emphasis should be placed on the doctrine of CT, especially in the aspect of granting managers the power to make critical decisions in the interest of the organization as well as the re-engineering of APSOs processes to fully incorporate IT.

Ghatari et al (2014) categorized the external barriers into technological, social, economic, and political. In PR, external barriers are those impediments that the organization has no significant control over which occurs from outside. For instance, APSOs don't have control of the system of government in operation. Same with government policies of IT infrastructure acquisition, management unwillingness to embrace change, lack of attention for the IT sector are other cases where APSOs cannot influence and control. These are external factors that stand against efficiency in APSOs.

\section{Harnessing Venkatraman's Model With Ghatari et al's Model: How PR Can Apply in APSOs}

Venkatraman's model reflects the need for organizations to progress from the evolutionary level, which harbours localized exploitation and internal (horizontal) integration which are self-seeking, to the revolutionary level, which categorizes levels as total business process redesign (reengineering), business network redesign and scope redefining (enhanced capacity). Venkatraman explained that the degree of business transformation in the evolutionary level is often low as ICT is applied for the mere purpose of enhancing employees' efficiency as well as the re-arrangement of elementary activities to achieve high-level work process through interlinking different applications and systems. However, according to Venkatraman (2004), there has to be a complete renovation of the work process to transit to the revolutionary level, where business process redesign is the first step and the renovation is expected to take effect even before the application of ICT to disable inefficient activities from being automated into the process. These inefficient activities have been identified by Ghatari et al (2014), as shown in figure 3, and are classified into five categories as political, technological, social, economic, and organizational.

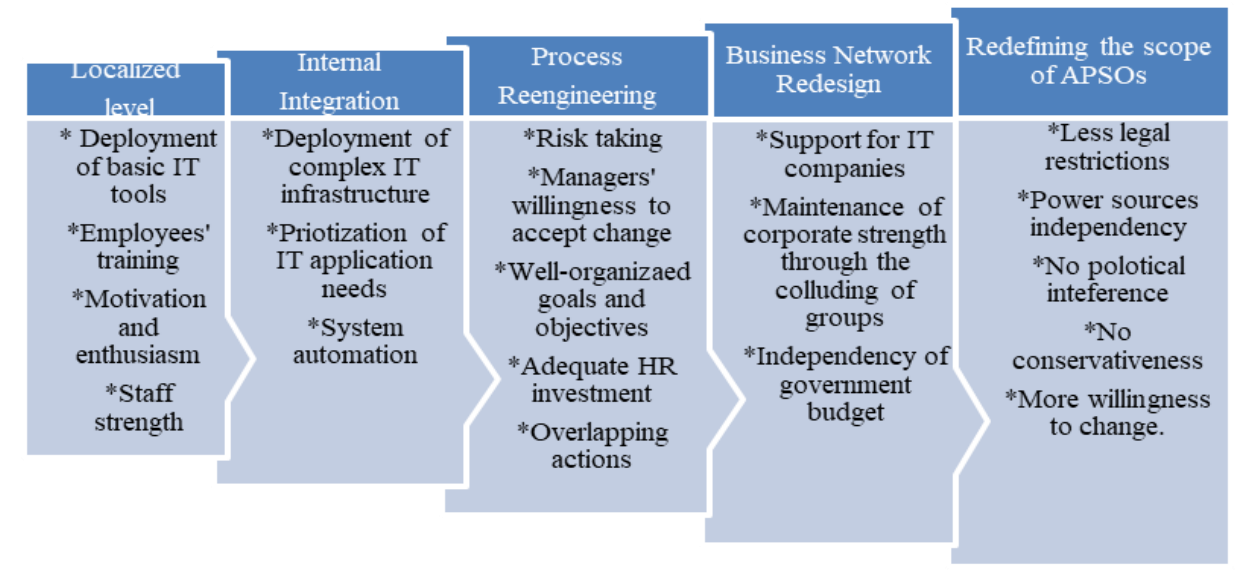

Figure 4. Applying PR in APSOs 
Source: Authors' compilation (2020).

Going by Venkatraman and Ghatari et al's models, for PSOs to fully embrace process reengineering, there has to be less political interference and senior managers must be willing to or/and allowed to take formal control of the organization with a reduction in the legal restrictions, laws, and regulations, irrespective of the system of government in current operation. The reduction of legal restrictions does not mean a total absence of laws and regulations but allowing PSO managers some freedom to make strategic decisions in the interest of the organization when the need arises (Venkatraman, 1994; Ghatari et al, 2014). Further, there should be concerns about the future of PSOs, and the citizens who are clients to PSOs, should be held to very high esteem as in the case of the private sector and their clients. Employees within PSOs should develop a good entrepreneurial spirit and willingness to embrace change through adequate preparedness to accept risk (Ghatari, et al, 2014). Lastly, Ghatari and Shamsi's model shows that over-dependency on the government budget, lack of attention to market needs, lack of adequate investment in process reengineering resources and lack of attention for IT sector are some of the reasons why PSOs in Africa cannot fully embrace any level of Venkatraman's model of PR.

\section{Internal Difficulties in PR Application in APSOs}

The APSOs continue to suffer from internal challenges to the application of PR as leadership structure both at the political and organizational level continue to scale below the expected average. One of the major causes of this problem is the changes that take place during elections as incoming government derives pleasure in installing their loyalists instead of maintaining experienced persons with proven integrity and several on-the-job pieces of training (Martin \& Montagna, 2006). This meets with a system that is not ready to change and embrace IT and the incorporation of relevant stakeholders. This reduces the scope of the entire process (Fountain, 2001). Further, the APSOs are not designed to overcome any restrictions posed by legislations, so managers are unduly restricted to only approve processes. Also, if any decision appears significant and necessary, it still faces hindrance in terms of majority acceptance, as not everyone is ready to accept change and the cost it carries (Joia, 2004).

To achieve process reengineering in APSOs, huge resources should be invested both in human and material aspects and there should be a clearer definition of the goals of participating parties ( $\mathrm{Wu}, 2002)$. Also, to fully automate the entire process, there should be less bureaucracy and more dependency on IT and its capabilities (Wimmer, 2002). Leadership in APSOs has affected PR in more ways than one. First, corrupt practices by politicians have led to the inability to fully maximize the potentials of PR. Second, managers in APSOs are deprived of express permission to effect necessary changes that are devoid of a bureaucratic bottleneck. Also, employees of APSOs have been found lazy in many aspects as a result of the nature of the requirements for promotion which is based on seniority instead of merit as obtainable in the private sector. PR requires constant training and retraining of employees to better be able to manipulate IT infrastructure to yield visible results. Further, institutional restrictions have hindered the smooth application of the manager's ingenuities, 
employees' talents, and change management processes. There is also a lack of resources and techno-centrism in APSOs. Finally, unnecessary extensions, employees' attitudes, and the inability of APSOs to properly define its objectives have hindered process reengineering application in APSOs.

\section{Critical Success and Failure Factors of $P R$ in Public and Private Sector Organizations}

This section attempts to modify Abdolvand et al's (2008) model of critical success factors (CSF) of PR as shown in figure 4. Abdolvand et al's model has been used to identify some structure decisions that have been adopted by managers in PrSOs that are known to produce with the implementation of PR (Virzi, 2019). However, the model failed to include the benefits of IT, which is the hallmark of process reengineering, especially in the public sector. Earlier, a study conducted by McAdam and O'Hare in 1998 to identify critical success factors in the public sector shows that as in the PrSOs, CSF is also important in PSO and there has to be top management commitment, open and effective communication, and teamwork (Habib, 2013). Proper communication, as rightly observed here, can best be driven by IT to serve cost and for more accuracy. Thus, the model presented in figure 4 below is modified by the authors to accommodate the benefits of IT as stated above.

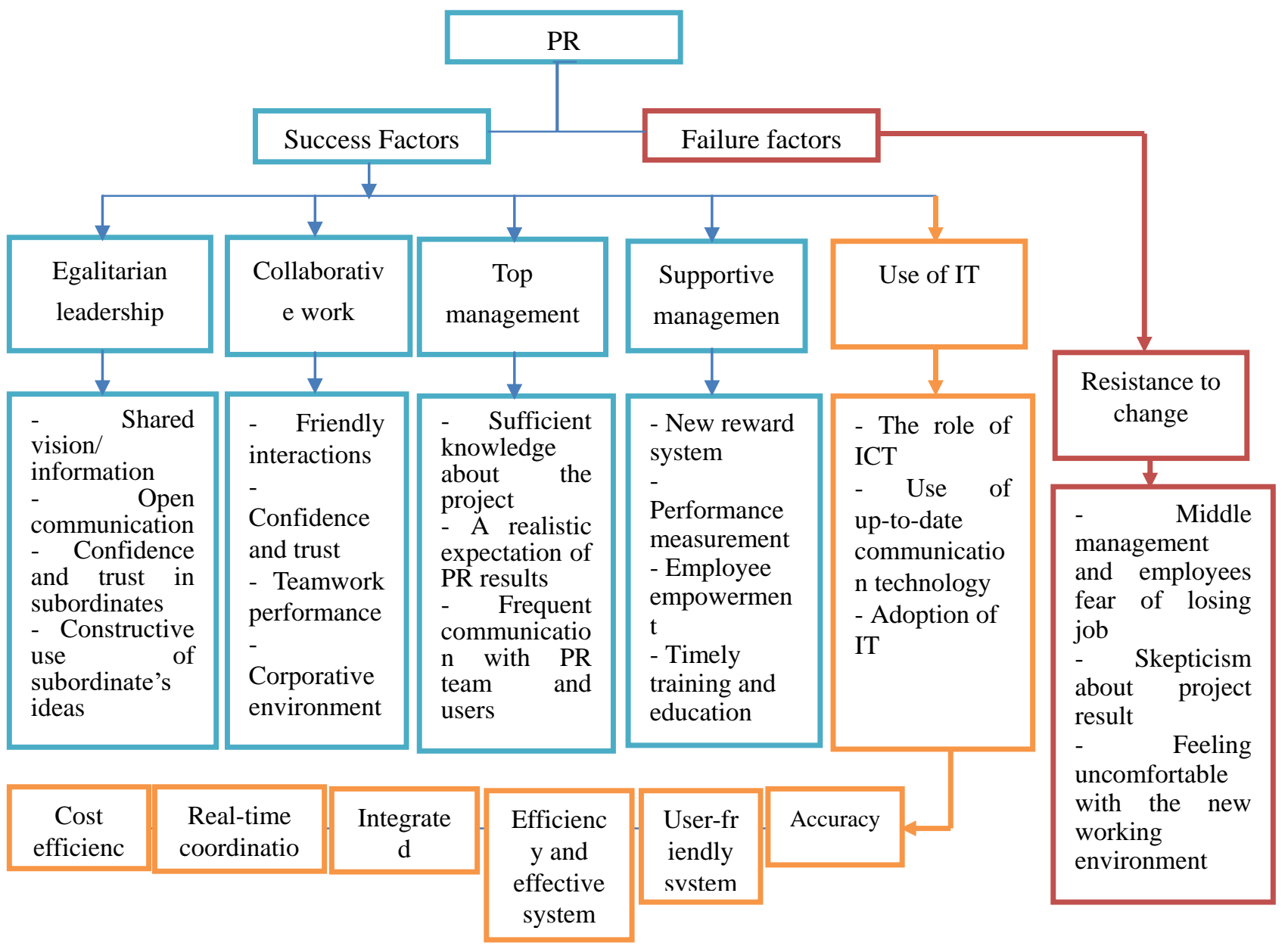

Figure 4. Modified Critical Success Model 
Source: Abdolvand Albadvi \& Ferdowski (2008); Authors' compilation (2020).

For more clarification, these factors presented in the figure are explained as follows:

Egalitarian leadership: this is a form of organizational leadership where top managers and team leaders look to the team for direction when faced with a project, decision, or plan that requires consensus. Here, when employees are clear about the channel of communication and the shared value of the organization or team (as the case may be), they become more responsive and tends to understand each other better (Grant, 2002; Motwani, Subramanian \& Gopalakrishina, 2005). Also, from this model, it is expected that top managers should create avenues for inter and intra-organizational confidence and trust, and optimal process operation (Terziovski, Fitzpatrick \& O’Neill, 2003). In an organization where an egalitarian leadership style is in operation, positive changes occur with little resistance (Crowe, Fong, Zayas-Castro, 2002; Ruedena, Alamib, Kaplanc \& Gurvenb, 2018).

Collaborative work environment: teamwork creates room for more effective and quicker service delivery as compared to projects that worked on an individual basis. When employees collaborate, they become more responsible, and their motivational level increases, especially when they work virtually. However, this can only be achieved in a friendly work environment where there is a free flow of interacting cooperation and mutual trust, with their respective roles being recognized by top management (Maull, Tranfield \& Maull, 2003; Assbeihat, 2016)

Top management commitment: when the board of directors formulates policies, it is expected that top management translates the same into goals and objectives, strategize on how to achieve the policy aim as well as project a shared vision of the future. Decisions made by top management affect everyone within the organization, hence, it is held responsible when a failure occurs (Tzempelikos, 2015; Syaifullah, 2017). In the words of Abdolvand et al (2008), "... it is necessary to have a piece of sufficient knowledge about the PR projects and realistic expectation of PR".

Supportive management: Unlike other forms of management and leadership, supportive management is less interested in just giving orders and/or managing every detail. Rather, it enables the employees to work themselves through the provision of necessary tools. One essential aspect of supportive management is the delegation of function. Therefore, reengineering the process has to do with redesigning the human resource architecture and other facilities to promote information sharing, decision making, and the achievement of organizational objectives (Vakola \& Rezgui, 2000; Baxter, 2013).

Use of information technology: IT remains one of the biggest enablers and soul of PR. Through IT, manual systems are computerized, virtual markers are made possible and there is increased efficiency and effectiveness of the work process (Arasteh, Aliahmadi, Mahmoodi, \& Mohammadpour, 2010).

Resistance to change: resistance to change is the only failure factor that has been identified by Abdolvand el at in their model of critical success and failure factors in PR in public and PrSOs. According to them, the fear of middle management and employees losing their job, 
skepticisms about project results, feeling uncomfortable with a new working environment constitute some of the resistance to change that stands as a failure factor in PR, especially in APSOs (Jain, Asrani \& Jain, 2018).

\section{Methodology for PR Application in APSOs and Lessons From the Private Sector}

As was stated in the introductory part of this paper, PR's adaptation in PSOs follows the wider trend of NPM, which emphasizes the introduction of core management principles like efficiency and accountability principles, organizational forms, etc into PSO's operations to help solve the challenge of "limited budget for ever-increasing demands" usually faced by PSOs (MacIntosh, 2003). The improvement in PSO's efficiency and service delivery have narrowed the gap between private and public organizations' management practices in many developed economies and is expected to do even more in less developed ones, especially in Africa. The applicability of PR in APSOs met with three dominant views;

\section{- $\quad$ Skepticism}

- Optimism

- Pragmatism

Skeptics believe that process reengineering (PR) is unsuitable to the characteristics of APSOs because the objectives of PSOs are different from that of the PrSOs. According to skeptics, while the former is aimed at providing essential and low-cost services, the latter aims at profit generation and maximization (Stemberger, Kovacic \& Jaklic, 2007). In contrast to the PrSO, the value definition in PSOs remains non-economic and subjective. Also, while the PSOs stakeholders measure service delivery in terms of equity and process transparency, the private sector stakeholders are more concerned with efficiency and effectiveness. Further, the level of acceptability to change differs in these organizations. It is on this basis that the skeptics posit that bureaucracy, interdependence, top-level administrators' turnover, less management authority and resistance to change are clogs on the wheel of successful PR in APSOs.

On the other hand, the optimists think that although the aim of PSOs is different from that of PrSOs, process reengineering is still needed in PSOs, especially in transformation, automation, speed, and modernization. In the words of Kassahun; "PR can serve as a key reform tool to transform the public sector from its existing hierarchical bureaucracy model into a customer-centric process model and to modernize it using the latest developments in IT" (Kassahun, 2012:61). This can be achieved if APSOs continue to rethink, radicalize, and redesign its activities to make way for powerful transformative ideas.

The performance problem as experienced in APSOs can be adequately addressed through the adaptation to process reengineering (PR) and a clear understanding of its CSFs which were discussed in the preceding part of this paper. Finally, the pragmatists think that although PR is applicable in APSO, there is need for a customized methodology owing to the unique characteristics of APSOs and lessons should be adapted rather than adopted from the private sector, together with keen attention to basic success and failure factors (Fragoso, 2015). The pragmatists also recognize several regulatory, statutory, and legal issues that affect swift PR 
principle application in APSOs and the need for major stakeholders to lend their weights on every proposed idea before acceptance, adoption, and application. Fragoso (2015) in his study disclosed that "the private sector PR methodology can be applied to the APSOs if a change institutionalization phase is included at the end and radical redesign is excluded because the public sector context does not lend itself to radical redesign". However, in the overall, the pragmatists believe in the applicability of PR in APSOs and this is expected to follow certain processes.

To achieve PR in APSOs therefore, IIE (1995), Manganelli \& Klein (1995), and Harbour (1995) have all agreed that there should be adequate preparation for a swift startup of the project (process) with well-defined limitations. This should be followed by identification and comprehension of the process which has been carefully observed (Step-by-step). This process should be designed in line with well gathered and analyzed data with a clear vision of the solutions it will proffer to business transactions. Further, there should be a readiness to embrace change, transformation, and improvements that are carefully monitored.

\section{Conclusion and Way Forward}

This paper $\mathrm{x}$-rayed PR in APSOs with emphasis on lessons to be learnt from the private sector, using the lens of the contingency theory which explains the need for the adoption of IT as well as the importance of granting powers to managers of APSOs to take urgent decisions as required by changes in the environment without any form of influence. It fills the gap in the literature by validating and modifying some theoretical models which highlight the importance of applying PR in APSOs. Some of the models validated in this paper are; Venkatraman's model for reengineering APSOs, and Ghatari et al's model of primary barriers to PSO's PR. Abdolvand et al's model of critical success and failure factors was also modified in the study to show key areas that may pose challenges to the adoption of IT in APSOs. This paper argues that the adoption of PR in PSOs will provide an excellent opportunity for high performance, better customer service and better way to manage resources in the interest of the public. Also, it further submits that a radical change is required in APSOs. This change is expected to be driven by PR with a focus on learning from the private sector where managers are given the powers to make urgent decisions when the need arises without being trapped in unnecessary bureaucratic processes. It has been discussed here that APSOs can fully adopt PR tools to achieve the needed performance and transformation. This can take effect after APSOs get rid of excessive bureaucracy that has continued to stand as a clog in the wheel of organizational transformation and performance. Finally, the paper explains some internal and external difficulties to PR application in APSOs as well as the role of IT. It suggests that:

1. There should be less political interference and senior managers should be allowed to take formal control of the organization with a reduction in the legal restrictions, laws, and regulations, irrespective of the system of government in current operation.

2. There should be the availability of IT infrastructure and the willingness on the part of the government to deploy new technologies through adequate support for IT companies and the prioritization of IT application's need for high system automation. 
3. There should be concerns about the future of PSOs and the citizens who are clients to public service organizations should be held to very high esteem and not to be treated as people in need of favour.

4. Promotion in African public sector organizations should be based on merit and not on seniority. This will trigger more seriousness and dedication to service excellence in the public sector.

5. Employees within PSOs should develop a good entrepreneurial spirit and willingness to embrace change through adequate preparedness to accept risk.

6. To achieve process reengineering in APSOs, huge resources should be invested both in human and material aspects and there should be a clearer definition of the goals of participating parties.

7. To fully automate the entire process, there should be less bureaucracy, more contingency planning and more dependency on IT and its capabilities.

8. There should be adequate preparation for a swift startup of the project (process) with well-defined limitations. The process should be designed in line with well gathered and analyzed data with a clear vision of the solutions it will proffer to transactions in APSOs.

\section{References}

Abdolvand, N., Albadvi, A., \& Ferdowsi, Z. (2008). Assessing readiness for business process reengineering. Business Process Management Journal, 14(4), 497-511. https://doi.org/10.1108/14637150810888046

Amanquah, B., \& Adjei, K. S. (2013). Business process reengineering (PR) in the financialservices sector: A case study of Ghana commercial bank (GCB) limited. European Journal of Business and Management, 5(29), 59-66

Andersen, K. V. (2006). Reengineering public sector organizations using information technology. in Eric E Otenyo and Nancy S Lind (eds.), Comparative public administration (Research in public policy analysis and management). Emerald Group Publishing Limited, 15, 615-634. https://doi.org/10.1016/S0732-1317(06)15027-7

Arasteh, A., Aliahmadi, A., Mahmoodi, H. S., \& Mohammadpour, M. O. (2010). Role of information technology in business revolution. Int $J$ Adv Manuf Technology. https://doi.org/10.1007/s00170-010-2834-9

Assbeihat, J. M. (2016). The Impact of Collaboration among Members on Team's Performance. Manag. Adm. Sci. Rev., 5(5), 248-259

Baxter, L. E. (2013). Supportive Leadership, Employee Engagement and Occupational Safety: A Field Study. PhD dissertation. University of Tennessee.

Bhaskar, H. L. (2014). PR as a quality improvement tool, Handbook of Management, Technology and Social Sciences. Noida: SEMS Publication. https://doi.org/10.2139/ssrn.2739368

Bhaskar, H. L. (2018). Business process reengineering: A process management tool. Serbian 
Journal of Management, 13(1), 63 - 87. https://doi.org/10.5937/sjm13-13188

Bokhari, A. S., \& Qureshi, R. J. (2016). Business process reengineering in public administration of the kingdom of Saudi Arabia. IT Information Engineering and Electronic Business, 4, 10-17. https://doi.org/10.5815/ijieeb.2016.04.02

Callender, G. (2001). Public Sector Organizations. In International Encyclopedia of the Social \& Behavioral Sciences, 1. Retrieved from: https://www.sciencedirect.com/topics/computer-science/public-sector-organization/pdf on April 23rd, 2020.

Crowe, T. J., Fong, P. M., Bauman, T. A., \& ZayasCastro, J. L. (2002). Quantitative risk level estimation of business process reengineering efforts. Business Process Management Journal, 8(5), 490-511. https://doi.org/10.1108/14637150210449148

Debela, T., \& Hagos, A. (2011). The design and implementation of business process reengineering in the Ethiopian public sector: $\mathrm{n}$ assessment of four organizations. African Books Collective Limited.

Debela, T. (2009). Business process reengineering in Ethiopian public organizations: the relationship between theory and practice. JBAS, 1(2), 21 -33. https://doi.org/10.4314/jbas.v1i2.57348

Duke, O. O., Okudero, G. O., Etim, E \& John, E. M (2020). E- Administration and public sector reforms in Nigeria: from the socio-technical doctrine. International Journal of Business Education and Management Studies, 4(1), 25-38.

Dutta, S. (2007). Recognizing the true value of software assets. INSEAD \& microfocus ltd. $1-29$.

Essam, M.M., \& Mansar, S.L. (2012). Towards a software framework for automatic business process redesign. ACEEE International Journal on Information Technology, 2(1), 23-28.

Fiedler, F. E. (1964). A theory of leadership effectiveness. In L. Berkowitz (Ed.), Advances in experimental social psychology. New York: Academic Press.

Fiedler, F. E. The contribution of cognitive resources to leadership performance. Journal of Applied Social Psychology, 16, 532-545. https://doi.org/10.1111/j.1559-1816.1986.tb01157.x

Fountain, J. (2001). Building the virtual state. Brooking Institution Press, 1

Fragoso, J. T. (2015). Business Process Reengineering in Government Agencies: Lessons from an Experience in Mexico. Journal of Service Science and Management, 8, 382-392. Retrieved from http://dx.doi.org/10.4236/jssm.2015.83040 March $27^{\text {th }}, 2020$. https://doi.org/10.4236/jssm.2015.83040

Ghatari, A. R., Shamsi, Z., \& Vedadi, A. (2014). Business process reengineering in the public sector: ranking the implementation barriers. Int. J. Process Management and Benchmarking, $X(X X)$. https://doi.org/10.1504/IJPMB.2014.063239 
Goksoy, A., Ozsoy, B., \& Vayvay, O. (2012). Business process reengineering: strategic tool for managing organizational change an application in a multinational company, International Journal of Business and Management, 7(2), 89-112. https://doi.org/10.5539/ijbm.v7n2p89

Grant, D. (2002). A wider view of business process reengineering. Communications of the ACM, 45(2), 84-92. https://doi.org/10.1145/503124.503128

Gull, R. (2017). Scientific Management; Concept, Principles, And Relevance. International Journal of Humanities and Social Science Invention, 6(11), 68-70.

Habib, N. M. (2013). Understanding Critical Success and Failure Factors of Business Process Reengineering. International Review of Management and Business Research, 2, 1-10.

Harbour, J. L. (1995) Manual de Trabajo de Reingeniería de Procesos. Panorama, México, D.F.

Harney, B. (2016). 'Contingency theory' in Johnstone, S. and Wilkinson, A. (2016). An Encyclopedia of Human Resource Management, Cheltenham: Edward Elgar, pp. 72-73.

Hussein, B., Hammoud, M., Bazzi, H., \& Haj-Ali, A. (2014). PRISM-Process reengineering integrated spiral model: An agile approach to business process reengineering (PR). International Journal of Business and Management, 9(10), 134-142. https://doi.org/10.5539/ijbm.v9n10p134

Institute of Industrial Engineers (1995) Más allá de la Reingeniería. CECSA, México, D.F.

Islam, J., \& Hu, H. (2012). A review of literature on contingency theory in managerial accounting. African Journal of Business Management, 6(15), 5159-5164. https://doi.org/10.5897/AJBM11.2764

Jain, P., Asrani, P., \& Jain, T. (2018). Resistance to Change in an Organization. Journal of Business and Management, 20(5), 37-43.

Johnson, A. (2011). Role of IT in PR. Slide share. 7. Retrieved from https://www.slideshare.net/abhinavjohnson/business-process-reengineering-PR-role-of-it on April $10^{\text {th }}, 2020$.

Joia, A. (2004). Developing Government-to-Government enterprises in Brazil: a heuristic model from multiple case studies, Internet Journal of Inform Management, 24, 147-166. https://doi.org/10.1016/j.ijinfomgt.2003.12.013

Kassahun, M. E. (2012). The effect of business process reengineering on public sector organization performance (a developing economy context). A thesis submitted for the degree of Doctor of Philosophy School of Business Information Technology and Logistics Business College RMIT University July 2012.

Kassel, D. S. (2010). Managing public sector projects: a strategic framework for success in an era of downsized government. Taylor \& Francis. https://doi.org/10.1201/9781420088748

Khan, A. R., \& Khandaker, S. (2016). Public and private organizations: how different or 
similar are they. Journal of Siberian Federal University. Humanities \& Social Sciences, 12, 2873-2885. https://doi.org/10.17516/1997-1370-2016-9-12-2873-2885

Köybaşi, F., Uğurlu, C. T., \& Bakir, A. A. (2017). The Factors that Influence Bureaucracy and Professionalism in Schools: A Grounded Theory Study. Journal of Education and Practice, $8(8), 196-207$

Kumar, R. (2016). Bureaucratic Theory by Max Weber - A Review Study. Journal of Advances and Scholarly Researches in Allied Education, XII(23), 212-216

Lai, C., \& Lin, S. H. (2017). Systems theory. The International Encyclopedia of Organizational Communication. Craig R. Scott and Laurie Lewis (Eds). John Wiley \& Sons, Inc. https://doi.org/10.1002/9781118955567.wbieoc203

Lilian, O. O., Uzochukwu, O. C., \& Francisca, O. N. (2015). Business process reengineering and organizational performance of selected automobile firms in southeast of Nigeria. European Journal of Business, Economics and Accountancy, 3(5).

Lucas, T. (2016). The application of business process re-engineering systems to enhance service delivery in the public sector. European Journal of Research in Social Sciences, 4(7), 13

MacIntosh, R. (2003). PR: alive and well in the public sector. International Journal of Operations and Production Management, 23, 327-345. https://doi.org/10.1108/01443570310462794

Manganelli, R. L., \& Klein, M. M. (1995) Cómo hacer Reingeniería. Norma, Bogotá.

Martin, R. L., \& Montagna, J. M. (2006). In TFTP International Federation for Information Processing, Volume 214, The Past and Future of transformation Systems: 1976-2006 and Beyond, eds. Avison, D., Elliot, S., Krogstie, J., Pries-Heje, J., (Boston; Springer), 77-88.

Mathew, G., Sulphey, M. M. \& Rajasekar, S. (2015). Scope of Business Process Reengineering in Public Sector Undertakings. Asian Social Science, 11(26), 129. https://doi.org/10.5539/ass.v11n26p129

Maull, R, Tranfield, D., \& Maull, W. (2003). Factors characterising the maturity of PR programmes. International Journal of Operations and Production Management, 23, 596-624. https://doi.org/10.1108/01443570310476645

Mekonnen, N. (2019). Implementing business process reengineering (PR) in government organization. Int. J. Adv. Res., 7(8), 109-120. https://doi.org/10.21474/IJAR01/9482

Morabito, V. (2013). Organizational absorptive capacity and the use of information. In Business Technology Organization, 129-142. Springer Berlin Heidelberg. https://doi.org/10.1007/978-3-642-32698-1_8

Mori, G. T. (2017). Examining Hindrance of Bureaucracy on Management Innovation for Organizations. International Journal of Academic Research in Business and Social Sciences, 7(4), 601-607. https://doi.org/10.6007/IJARBSS/v7-i4/2835 
Motwani, J., Subramanian, R., \& Gopalakrishna, P. (2005). Critical factors for successful ERP implementation: exploratory findings from four case studies. Computers in Industry, 56, 529-44. https://doi.org/10.1016/j.compind.2005.02.005

Nchuchuwe, F. F., \& Etim, E. (2020). Human capital development and service delivery in Lagos State: A study of selected ministries. Asian Journal of Advanced Research and Reports, 12(2), 10-19. https://doi.org/10.9734/ajarr/2020/v12i230283

Oberoi, R. (2013). Applying Business Process Re-Engineering to Public Sector as A New Public Management Strategy. Journal of Government and Politics, 4(2), 292-304. https://doi.org/10.18196/jgp.2013.0017

Omoluabi, E. T. (2016). Contingency approach in Nigeria management system. Information and Knowledge Management, 6(7), 1-7

Prakken, B. (2000). Information, organization and information systems design: an integrated approach to information problems. Springer Science \& Business Media, 186. https://doi.org/10.1007/978-1-4615-4421-0_5

Rezaie, S. (2018). Why our public sector organizations need Business Process Re-engineering? Retrieved from http://outlookafghanistan.net/topics.php?post_id=19902\#ixzz6Ht0gXwxP on April 15 ${ }^{\text {th }}, 2020$

Ruedena, C., Alamib, S., Kaplanc, H., \& Gurvenb, M. (2018). Sex differences in political leadership in an egalitarian society. Evolution and Human Behavior, 39(4), 402-411. https://doi.org/10.1016/j.evolhumbehav.2018.03.005

Samier, E. A. (2012). Bureaucratic Theory Myths, Theories, Models, Critiques. The Handbook of Educational Theories. Information Age Publishing, Inc., 901-907.

Scholl, H. J. (2003). E-government: a special case of ICT-enabled business process change. 36th Hawaiian International Conference on System Sciences, Waikoloa, Big Island, Hawaii. https://doi.org/10.1109/HICSS.2003.1174309

Scott, W. R. (1981). Organizations: Rational, Natural, and Open Systems. Englewood Cliffs NJ: Prentice Hall Inc.

Serpa, S., \& Ferreira, C. M. (2019). The Concept of Bureaucracy by Max Weber. International Journal of Social Science Studies, $7(2), \quad 12-18$. https://doi.org/10.11114/ijsss.v7i2.3979

Shaikh, I. A., Islam, A., \& Jatoi, B. A. (2018). Bureaucracy: Max Weber's Concept and Its Application to Pakistan. International Relations and Diplomacy, 6(4), 251-262. https://doi.org/10.17265/2328-2134/2018.04.004

Sia, S., \& Neo, B. (2008), Business process reengineering, empowerment and work monitoring. Business Process Management Journal, 14, 609-628. https://doi.org/10.1108/14637150810903020 
Simasiku, P. L., \& Ngoma, J. (2018). Business process reengineering. Is Zambia's manufacturing industries aware of the benefits that this strategy brings?. International Journal of Scientific \& Engineering Research, 9(2), 1-5.

Stemberger, M. I., Kovacic, A., \& Jaklic, J. (2007). A Methodology for Increasing Business Process Maturity in Public Sector. In Kathy Lynch (ed.). Interdisciplinary Journal of Information, Knowledge, and Management, 2, 119-133. https://doi.org/10.28945/104

Sudhakar, G. P. (2010). The Role of IT in Business Process Reengineering. ECONOMICA. P. $33 . \quad$ Retrieved from https://www.researchgate.net/publication/237050536_The_Role_of_IT_in_Business_Process _Reengineering on April 23rd, 2020.

Sujová, E., \& Čierna, H. (2018). Optimization and improvement of test processes on a production line. Management Systems in Production Engineering, 26, 88-92. https://doi.org/10.2478/mspe-2018-0014

Surbhi, S. (2018). Difference between public sector and private sector. Retrieved from https://keydifferences.com/difference-between-public-sector-and-private-sector.html\#Definiti on on March $28^{\text {th }}, 2020$

Syaifullah, M. (2017). The influence of top management commitment and organizational culture on implementation of management accounting information system a study at people's credit banks (bpr) in Pontianak City, Indonesia. International Journal of Economics, Commerce and Management, 5(12), 460-482.

Terziovski, M., Fitzpatrick, P., \& O’Neill, P. (2003). Successful predictors of business process reengineering (PR) in financial services. International Journal of Production Economics, 84, 35-50. https://doi.org/10.1016/S0925-5273(02)00378-X

Tzempelikos, N. (2015). Top management commitment and involvement and their link to key account management effectiveness. Journal of Business \& Industrial Marketing, 30(1), 32-44. https://doi.org/10.1108/JBIM-12-2012-0238

Uddina, N., \& Hossain, F. (2015). Evolution of modern management through Taylorism: An adjustment of Scientific Management comprising behavioral science. The 2015 International Conference on Soft Computing and Software Engineering. Procedia Computer Science, 62, 578 - 584. https://doi.org/10.1016/j.procs.2015.08.537

Vakola, M., \& Rezgui, Y. (2000). Critique of existing business process re-engineering methodologies - the development and implementation of a new methodology. Business Process Management Journal, 6(3), 238-50. https://doi.org/10.1108/14637150010325453

Venkatraman, N. (1994). IT-Enabled business transformation: from automation to business scope redefinition. Sloan management review, 35(2), 73-87.

Virzi, K. (2019). Examining the Success and Failure Factors of Business Process Reengineering in Africa, Asia, the Middle East, and North America: A Literature Review. Open Access Library Journal, 6: e5722. https://doi.org/10.4236/oalib.1105722 


\section{Macrothink}

Journal of Public Administration and Governance ISSN 2161-7104 2020, Vol. 10, No. 3

Vrček, N., Brumec, J., \& Ibrahimpašić, D. (2009). Measuring effects of business process engineering in public sector-a case study. IADIS International Conference Information Systems. 121-127

Wimmer, W. (2002). A European perspective towards online one-stop government. the eGOV project Electronic Commerce Research and Applications, 1, 92-103. https://doi.org/10.1016/S1567-4223(02)00008-X

Wu, I. L. (2002). A model for implementing PR based on strategic perspectives: an empirical study. Information $\quad$ \& $\quad 313-324$. https://doi.org/10.1016/S0378-7206(01)00099-4

Yazaki, Y. (2016). The effects of bureaucracy on political accountability and electoral selection (July 1, 2016). https://doi.org/10.2139/ssrn.2851673

\section{Copyright Disclaimer}

Copyright for this article is retained by the author(s), with first publication rights granted to the journal.

This is an open-access article distributed under the terms and conditions of the Creative Commons Attribution license (http://creativecommons.org/licenses/by/4.0/). 